\title{
Supporting hydrogen based transportation: case studies with Global MARKAL Model
}

\author{
Daniel A. Krzyzanowski · Socrates Kypreos • \\ Leonardo Barreto
}

Published online: 17 February 2007

(C) Springer-Verlag 2007

\begin{abstract}
Steadily growing prices of oil and emissions coming from conventional vehicles, might force a switch to an alternative and less polluting fuel in the coming future. In this article we analyze the potential influence of selected factors for successful market penetration of hydrogen fuel cell vehicles in hydrogen based private transportation economy. Using a world scale, full energy system, bottom-up, optimization model (Global MARKAL Model-GMM) we address the possibility of supporting the fuel cell vehicle technology to become competitive in the markets. In a series of optimizations we evaluate the potential influence of governmental supports and the internalization of externalities related to $\mathrm{CO}_{2}$ and local pollution emissions originating from the transportation sector, as well as preferential crediting options and demonstration projects promoting fuel cell vehicles. The results suggest that the crucial element is the price of fuel cells and their further potential to reduce costs. This reduction of costs may be triggered by governmental support such as direct subsidies to fuel cells, preferential crediting options for the buildup of hydrogen infrastructure as well as penalization of emitters of $\mathrm{CO}_{2}$ and/or local pollutants.
\end{abstract}

Keywords Fuel cell vehicles - MARKAL - GMM - $\mathrm{CO}_{2}$ cost internalization $\mathrm{SO}_{2} / \mathrm{NO}_{x}$ cost internalization $\cdot$ Externalities

\section{Introduction}

MARKAL, the bottom-up, optimization model (in numerous versions) has been known among the scientific community for many years now. With the

D. A. Krzyzanowski · S. Kypreos $(\bowtie) \cdot$ L. Barreto

Energy Economics Group, Laboratory of Energy Systems Analysis, Paul Scherrer Institut, CH-5232 Villigen-PSI, Switzerland

e-mail: socrates.kypreos@psi.ch 
ability to portray the full energy sector, MARKAL is a robust tool for analysis aiming at establishment of long-term forecasts of optimal energy mixes and technological change. Many studies carried out using MARKAL have been focused on issues related to generation of heat and electricity, related consumption of primary fuels (renewable and conventional) and resulting environmental burdens. In this study we have made an attempt to use this modeling framework and elaborate on the transportation sector, which is one of large energy-intensive sub-system. The transportation sector is an all-present and vital part of every country's economy. It serves for the commuting citizens and movement of goods and in doing so supports the economic development. As the economies develop, there is an observable increase in the demand for transportation - both in the passenger and freight sub-sectors. This increase for transportation demand has many, long-term implications such as depletion of primary resources (fuels), on which transportation is very dependant, and an increase in carbon dioxide and local pollutants emissions, originating primarily from road vehicles.

In the past years, the concerns for the sustainable development and operation of the transportation sector have been broadly discussed especially in highly industrialized regions like Europe or North America. The environmental burdens carried by the currently functioning oil-based transportation system, to a significant extent, contribute to the emissions of $\mathrm{CO}_{2}$ as well as nitrogen, particulate matter and sulfur oxides. These environmental pollutants have a major negative impact on the well being of societies. As reported by the European Commissions Project "ExternE" (Rabl and Spadaro 2000) the vast majority (over 95\%) of the total damage costs is due to health impacts, and among health costs the dominant item is reduced life expectancy. Chronic bronchitis is also important, and so are impacts for asthmatics. Cancers have also been quantified, but their contribution to the total cost is very small." To address this issue, estimates have been prepared on the financial impacts of externalities (negative effects of pollutant emissions).

Therefore, in the light of the constantly growing demand for transportation and its resulting side effects, many claim that by mid century mankind might be looking for other options as to mitigate the negative impacts of the current transportation system. These options might include changing to more efficient, but still petroleum based, technologies, switching to a different, more environmentally friendly fuel or switching to alternative modes of transportation. One such option which is broadly discussed is hydrogen based mobility, in which hydrogen is used as fuel for vehicles. As long term perspective this option is often discussed also in terms of hydrogen fuel cell vehicles which do not use combustion as means of converting hydrogen to energy (Wokaun et al. 2004).

Today, vehicles based on fuel cells, and fuel cells themselves are not commercially available, while the hydrogen infrastructure is, in essence, non-existent. Nevertheless, considering the progress which has been achieved in the fuel cell technology during the last 10 years, one could imagine that in the coming 25 years (i.e., by the year 2030) it could be possible that the research in fuel cell technology overcomes technical and economical difficulties and allows for 
preliminary, mass scale, market deployment. Nevertheless, one could foresee that if major technical and economical difficulties are resolved, there might still be a need for additional support as to allow the beginning of the transition to a hydrogen based transportation.

In this work we have focused on evaluating if the proposed alternative for the transportation sector, namely hydrogen fuel cell vehicles, may indeed become a long-term solution. Due to the fact that from today's perspective this solution may be questionable, using the Global version of MARKAL Model we have tested the mentioned alternative in the presence of supporting policies. Section 2 of this article describes in general the modeling framework of GMM. Next, in Sect. 3 we present how the transportation sector has been introduced into the GMM framework in terms of demands, technology specifications and fuel prices. Section 4 then, presents the baseline case, which portrays the development of the transportation sector within GMM without any policy measures. Later, in Sect. 5 , we present how and why governmental bodies and the car industry may contribute to the possible switch towards hydrogen based transportation sector focusing on selected aspects of environmental impacts and other options that employ different policy measures promoting hydrogen based transportation systems. Lastly, in Sect. 6 we present the final conclusions of the analysis.

\section{GMM: the modeling framework}

Successful climate policy assessment together with the assessment of future technologies in the transportation sector requires the use of models able to stimulate the technological change necessary for long-term shifts towards a low-carbon global energy system. The Global-MARKAL Model (GMM) is a multi-regional, partial equilibrium "bottom-up" engineering model of the energy system that incorporates endogenous technological learning with spillovers across technologies and world regions. The model includes sufficient technological details for being able to address the question of how policies can foster the development of new technologies and their subsequent deployment.

GMM considers five world regions: Two regions represent the industrialized countries: North America (NAM) and the rest of the countries belonging to the OECD in 1990 (OOECD). OOECD comprises Western Europe and the so-called Pacific OECD region (which includes Japan, Australia and New Zealand). One region represents the economies-in-transition, putting together the Former Soviet Union and Eastern Europe (EEFSU). The developing world is grouped in two additional regions. Developing countries in Asia are included in the ASIA region. ASIA comprises centrally planned Asia, South East Asia and Pacific Asia. The rest of the world is covered in the LAFM region, which includes Latin America, Africa and the Middle East.

Each time a set of policy assumptions is simulated, the model clears the energy markets by a partial equilibrium approach that maximizes the producers and consumers surplus. The study is optimistically assuming that the institutional frameworks are adjusted such that market oriented policies, like marginal costs pricing apply. 
GMM considers demands for industrial, residential, commercial and the transportation sectors. Additional categories represent non-commercial uses of biomass and non-energy feedstock. Assumptions concerning energy intensity and energy demand projection per region and demand category are trend extrapolation of the past performance on autonomous declining energy intensity together with a consideration of regional income and price elasticities. The model horizon is $1990-2050$ while a discount rate of $5 \%$ is applied to all calculations.

Addressing the policy questions stated above requires an adequate treatment of technology dynamics in energy-systems models. In this study, the attention focuses on technological learning, a key driving force of technological progress. Learning plays an important role in cost/performance improvement of technologies, stimulating the competition and continuous substitution between them in the marketplace. The endogenization of technology learning (ETL) represents an advance in the representation of technological change in energy-system optimization models, capturing the early investments (i.e. early accumulation of experience and/or R\&D knowledge stock) required for a technology to progress and achieve long-term cost competitiveness. The GMM model endogenizes the one-factor learning curves, or "experience" curves where cumulative installed capacity is used as a proxy for accumulated experience.

In that case the reduction of specific investment costs is defined as function of cumulative installations:

$$
\mathrm{SC}_{t}=\alpha \cdot \mathrm{CC}_{t}^{-\beta} \quad \text { with } \beta=\frac{\ln (1-\mathrm{LR})}{\ln 2}
$$

where $\mathrm{SC}$ is the specific cost of a technology, CC the cumulative installations and LR the learning rate that reflects the specific cost reduction for each doubling of experience. In the case of a hydrogen fuel cell stack, we assume that the learning rate is $15 \%$ for each doubling of production. Given that technology learning is an increasing-returns phenomenon, the above formulation of learning in GMM, defines a non-linear and a non-convex optimization problem.

Conventional non-linear programming solvers are only able to identify locally optimal solutions and global optimization solvers can be applied only to smallscale problems (Manne and Barreto 2004). In order to avoid non-convexity and non-linearity, the integral of total investment costs for a technology is expressed in terms of a linearised mixed integer programming (MIP) formulation based on the following relation:

$$
\mathrm{TC}_{t}=\int_{t_{0}}^{t} \mathrm{SC}_{t} \cdot \mathrm{dCC}=\int_{\mathrm{CC}_{0}}^{\mathrm{CC}_{t}} \alpha \cdot \mathrm{CC}_{t}^{-\beta} \cdot \mathrm{dCC}=\alpha /(1-\beta) \cdot\left(\mathrm{CC}_{t}^{1-\beta}-\mathrm{CC}_{t_{0}}^{1-\beta}\right)
$$

Thus, for the above representation of learning, a piece-wise linear approximation of the integral on investments is implemented in a MIP formulation that allows to identify global optimal solution for the linearised problem. Moreover, 
efficient MIP commercial solvers permit handling technology learning in multiple technologies. Box 1 presents a summary of this MIP formulation. For a more detailed description of the MIP approach in the GMM model see Barreto (2001) and Barreto and Kypreos (2004). More information on ETL is given by (Laitner and Sanstad 2004; Ogden et al. 2004; Barreto and Kypreos 2004) while the equations of the MARKAL family of models is described by (Loulou et al. 2004) and is not included here. The calculation time of a single GMM run, on a $3 \mathrm{GHz}$ dual core system, ranges from 30 to $45 \mathrm{~min}$.

Box 1: Description of the Mixed Integer Programming approach to endogenize technology learning in the GMM model

- The cumulative capacity of a given technology te in the period $t$ is defined as

$$
\mathrm{CC}_{\mathrm{te}, \mathrm{t}}=\mathrm{CC}_{\mathrm{te}, 0}+\sum_{\tau=1}^{t} \mathrm{INV}_{\mathrm{te}, \tau} \quad \text { te } \in\{1, \ldots, \mathrm{TE}\}, \mathrm{t} \in\{1, \ldots, T\}
$$

The parameter $C_{\mathrm{te}, 0}$ is the initial cumulative capacity (the corresponding cumulative cost $\mathrm{TC}_{t e, 0}$ is also defined). The variable $\mathrm{INV}_{\mathrm{te}, t}$ represents the investments made on this technology in a particular period $t$.

- The cumulative capacity is expressed as a summation of continuous lambda variables:

$$
\mathrm{CC}_{\mathrm{te}, t}=\sum_{i=1}^{N} \lambda_{\mathrm{te}, i, t}
$$

- The cumulative cost is expressed as a linear combination of segments expressed in terms of the continuous lambda and binary delta variables:

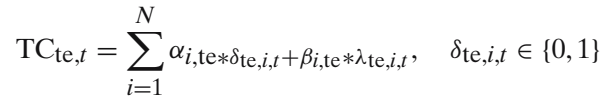

with

$$
\beta_{i, \mathrm{te}}=\frac{\mathrm{TC}_{i, \mathrm{te}}-\mathrm{TC}_{i-1, \mathrm{te}}}{\mathrm{CC}_{i, \mathrm{te}}-\mathrm{CC}_{i-1, \mathrm{te}}} \quad \text { and } \quad \alpha_{i, \mathrm{te}}=\mathrm{TC}_{i-1, \mathrm{te}}-\beta_{i, \mathrm{te}} \mathrm{CC}_{i-1, \mathrm{te}}
$$

- The logical conditions to control the active segment of the cumulative curve are

$$
\lambda_{\text {te }, i, t} \geq \mathrm{CC}_{i, \text { te }} * \delta_{\text {te }, i, t}, \quad \lambda_{\text {te }, i, t} \leq \mathrm{CC}_{i+1, \text { te }} * \delta_{\text {te }, i, t}
$$

- The sum of delta binary variables is forced to one:

$$
\sum_{i=1}^{N} \delta_{t e, i, t}=1
$$

- Using the fact that experience must grow or at least remain at the same level, additional constraints are added to the basic formulation, helping to reduce the solution time.

For $t=1, \ldots, T$, te $=1, \ldots, \mathrm{TE}, i=1, N$

$$
\sum_{P=1}^{i} \delta_{t e, P, t} \geq \sum_{P=1}^{i} \delta_{t e, P, t+1}, \quad \sum_{P=i}^{N} \delta_{t e, P, t} \leq \sum_{P=i}^{N} \delta_{t e, P, t+1}
$$

- The investment cost $\mathrm{IC}_{\mathrm{te}, t}$ associated to the investments in learning technologies is computed as

$$
\mathrm{IC}_{\mathrm{te}, t}=\mathrm{TC}_{\mathrm{te}, t}-\mathrm{TC}_{\mathrm{te}, t-1}
$$

The discounted investment cost is included in the objective function. 


\section{Transportation sector within GMM}

The supply side of energy systems (heat and electricity) is presented in GMM by means of technological chains. These chains comprise extraction of fuels, their conversion to final energy (heat or electricity), transmission and final distribution. The transportation sector has been modeled using the same principle, with the difference that energy generation and conversion technologies have been adapted to the needs of the transportation sector and energy demands have been defined as vehicle kilometers.

As in the case of other energy sectors within GMM, each of the technological steps in the transportation sector (generation, conversion, transmission, distribution, etc.) is described with technological, environmental and economical parameters. The diagram below, illustrates a simplified representation of the transportation sector as used in GMM (Fig. 1).

The end use technology representation is later linked with appropriate, region specific, time dependant demands. The regional demands for passenger cars and buses have been derived from the correlations between regional GDP/capita, Travel Time Budget and performance of different modes of transport. This methodology assumes that citizens, on average, spend around $1 \mathrm{~h}$ for travel (Travel Time Budget) every day. As their income level rises (represented by GDP/Capita index) they switch to faster and more expensive modes of transport (Schafer and Victor 2000).

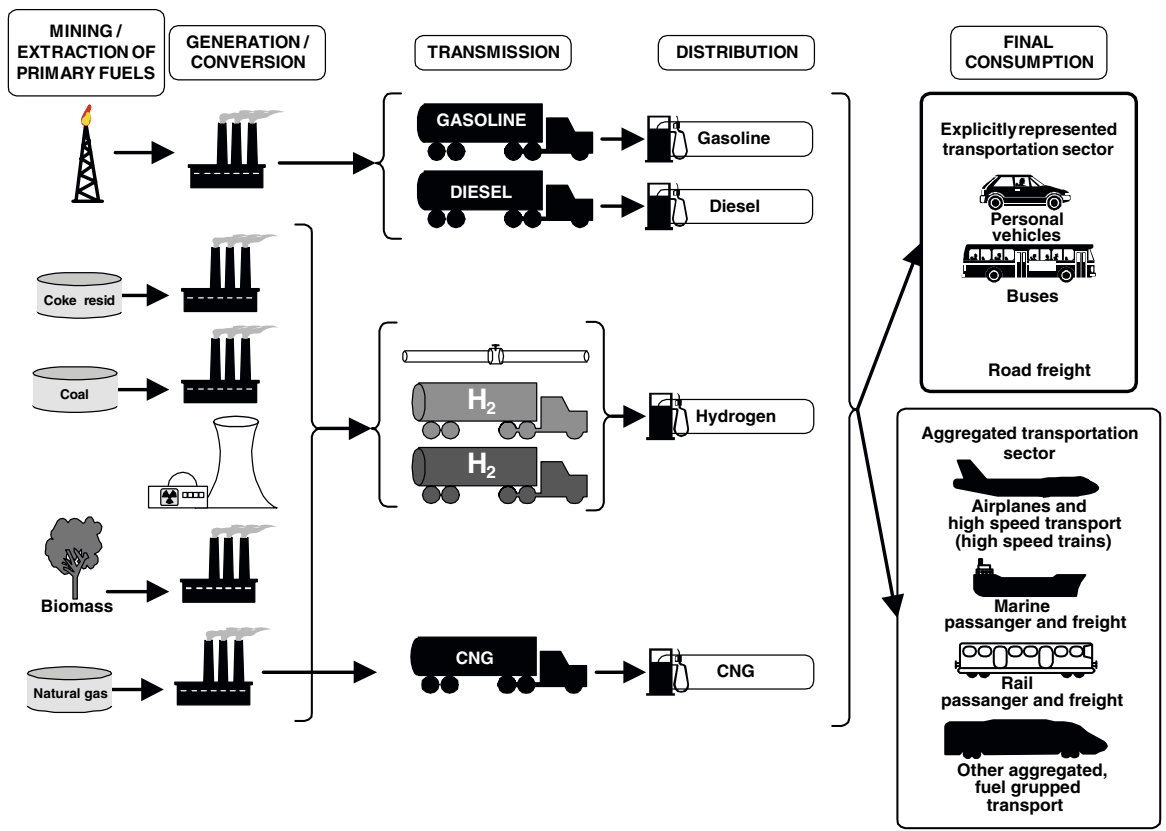

Fig. 1 Simplified illustration of representation of the transportation sector in GMM 
Regional demands for freight transportation (Fig. 2) for the first year, and the calibration of GMM in terms of other vehicle shares, their regional performance, taxation of fuels, etc. have been prepared on the basis of the following region specific data (World Energy Council 1998; World Energy Council and International Institute for Applied Systems Analysis (IIASA) (1998); BTS (2000); US Department of Transportation (2000); Babiker et al. (2001); Luxembourg Office for Official Publications of the European Communities (2001); Heston et al. (2002); Suurs (2002); US Department of Transportation (2002); IEA (International Energy Agency) (2002a); Litman (2003); OECD (2003); IEA (International Energy Agency) (2004); IFTA (2004); BP (2005)).

Regional demands for road freight transportation is based on own projections. As basis for the projections of regional road freight demands, we used statistical data on the amounts of cargo moved in each of the five regions of GMM in the pre-2000 year periods. Having established the pre-2000 demands, we then made extrapolations into the year 2050. As driver for this extrapolation we have considered such indicators as population, GDP, purchasing power parity (PPP), and their various combinations. For our demand projections we established region specific, linear or quadratic correlations between the activity of the road freight transportation and the GDP/capita indicator (IIASA B2 scenario; Nakicenovic and Swart 2000). These region specific correlations have resulted in a deviation of $R^{2}$ value in the range of 0.94 , which has been far the best as compared to other indicators considered.

The remaining modes of transport, for which more detailed projections could not be prepared, were subject to simplified approach. The remaining modes have been aggregated on the basis of fuel used (Fig. 1), while their time dependant development was extrapolated, from the statistics-calibrated value for the year 2000 , with a growth rate of $5 \%$ per decade.

The transportation sector is however comprised not only of personal cars, buses and road freight. Due to limited availability of reliable data and in order

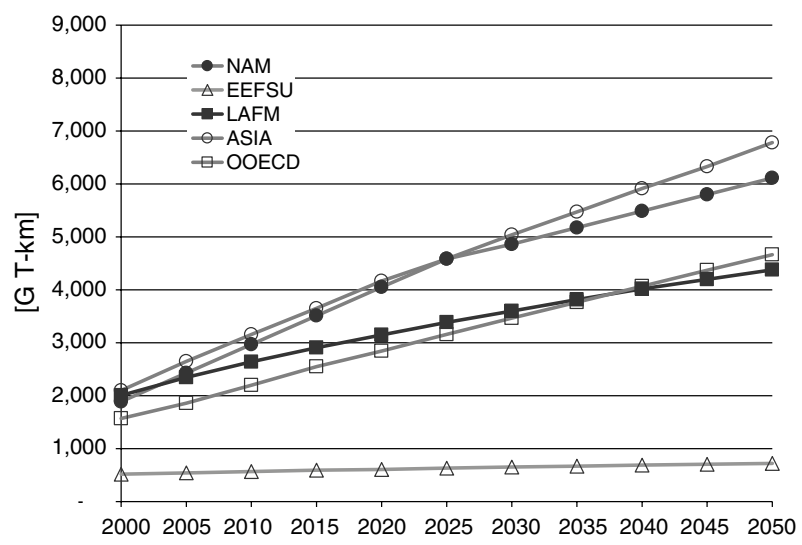

Fig. 2 Demand for freight transportation, as used for five regions of GMM 
to match the available statistical data we have aggregated the remaining modes (such as passenger air, marine passenger and freight, etc.) and applied a constant growth rate as specified in Table 5 .

The parameters for the technologies and conditions used in the analysis with GMM have been specified in the following tables (Tables 1, 2, 3, 4, 5).

Figure 3 illustrates costs of travel by a standard-model car. In respect to the hydrogen fuel cell vehicle the bars indicate the costs at the beginning of market deployment and at the moment the technology has reached full maturity, when no cost reduction is possible anymore.

The price of fuel cells, at early stages of their market deployment is very high. This puts the fuel cell vehicles in an unfavorable position in terms of economic attractiveness. However, provided that initiatives arise, there is a potential for industrial producers to reduce the cost of this crucial element as a result of the increasing demand.

\section{GMM: the Baseline case}

The starting point of the analysis was the development of the "base case" which allocates the energy use and technologies in the markets according to overall, least-cost optimization. The base case is therefore free of any external interventions like governmental support or extra fiscal burdens. The specific conditions of the Base-case have been specified in Table 5.

In the base case of GMM, as illustrated below (Fig. 4), the first 30 years of the century are primarily dominated by two types of vehicles, namely those powered by gasoline and diesel internal combustion engines. Later on, as the hybrid technology becomes mature, it is the gasoline-electric hybrid that begins to dominate the market. Judging by today's rate of developments in the fuel cell technologies, we have assumed that by the end of the first quarter of the century, major fuel cell producers and developers will be able to solve technical problems related to the operation of fuel cells (like limited life time of membranes), and by the time the fuel cells are ready for preliminary market launch, their price is at the level of $600 \mathrm{US} \$ / \mathrm{kW}$. Moreover, manufacturers of fuel cell see possibilities for further cost reduction, provided that a significant demand for fuel cells would appear (fuel cell learning rate 15\%). Additionally, steadily growing oil prices (oil price reaches an average of around $70 \mathrm{US} \$ / \mathrm{bbl}$ by the end of the modeling timeframe) which are unfavorable for vehicles based on conventional fuels, suggest that a change to an alternative and sustainable transportation option could be feasible. Despite all of the favorable conditions for hydrogen based mobility, the hydrogen transportation does not lift off. This is mainly due to the fact, that fuel cells are still too expensive for potential customers; additionally the potential customer is faced with a problem of limited access to the fuelling network. The lack of fuelling facilities is in a way a "chicken\&egg" problem. Fully fledged fuelling infrastructure is not constructed, as no noticeable demand exists; while on the other hand, no demand can be triggered as the potential buyers see significant drawbacks in the possibilities of 


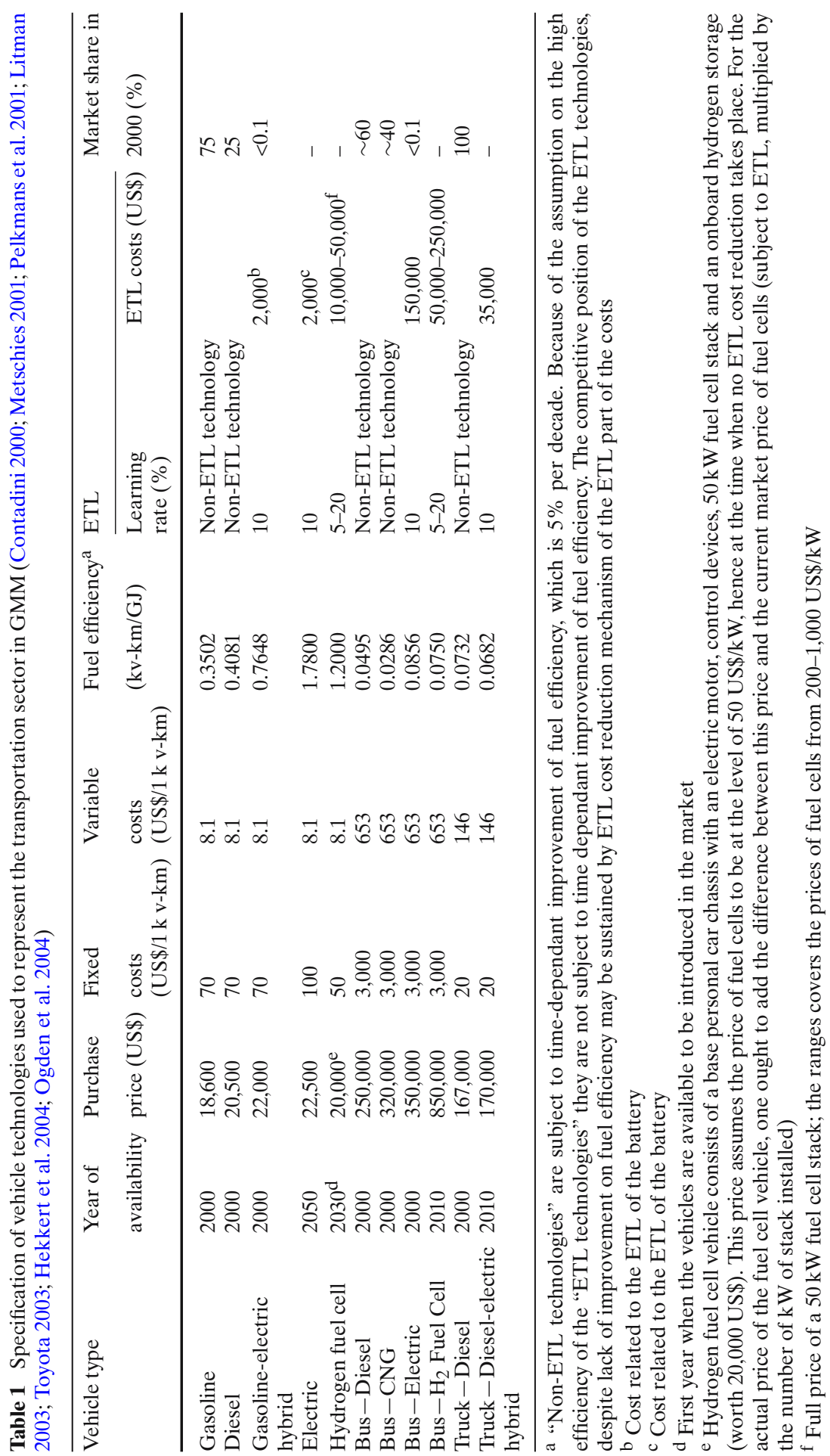




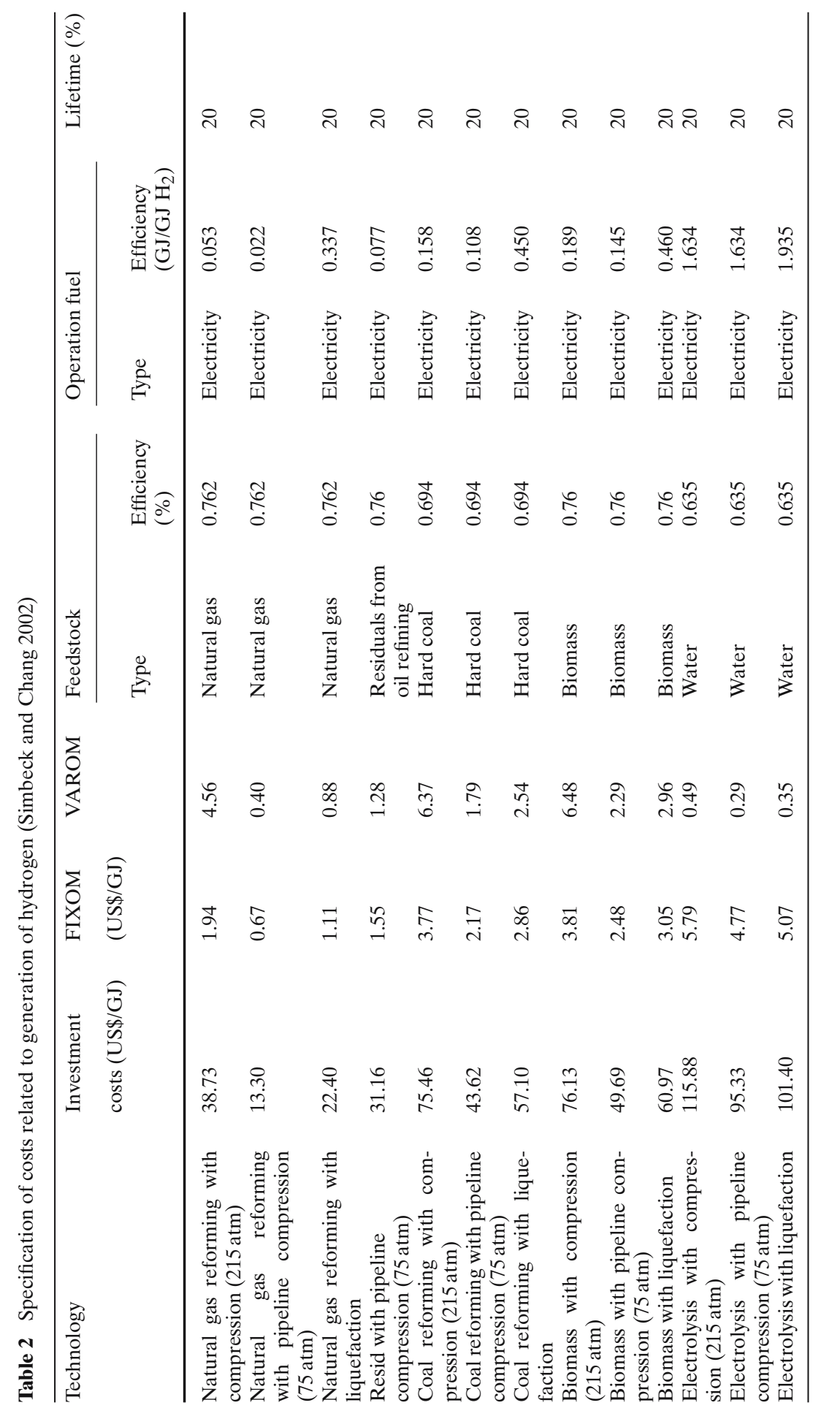




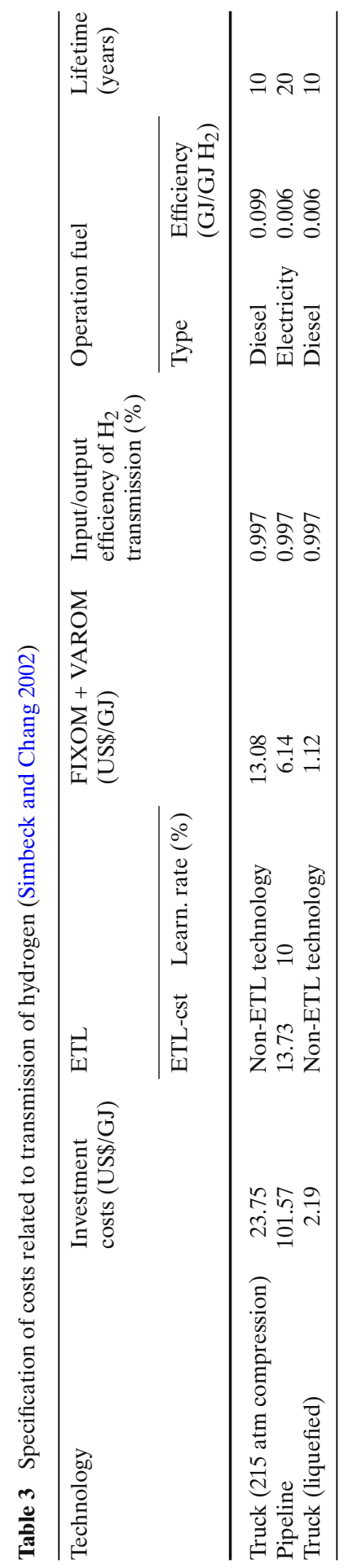




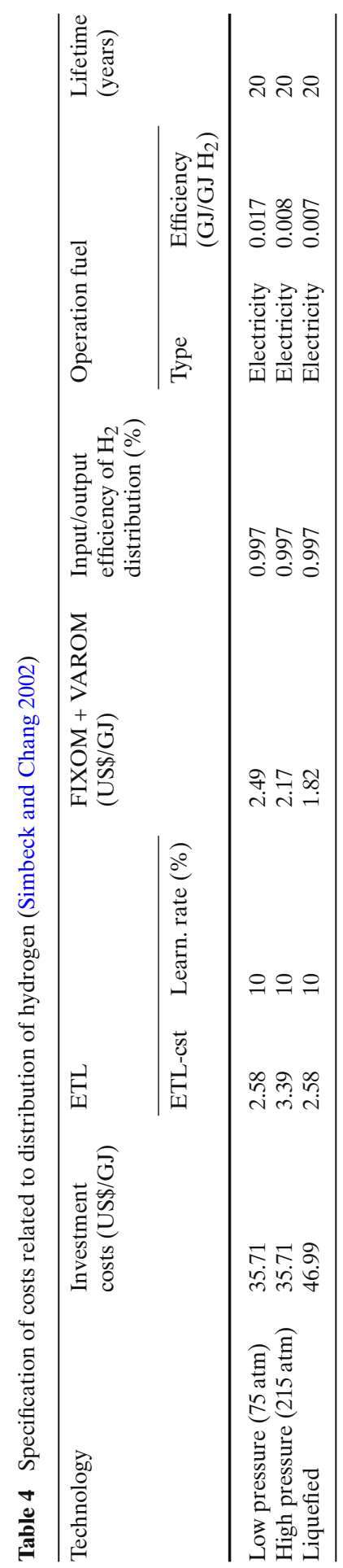


Table 5 Specification of conditions in the analysis with GMM

\begin{tabular}{|c|c|}
\hline Parameter & Value \\
\hline \multirow[t]{3}{*}{ Oil price } & Average 28 US\$/bbl (2000) \\
\hline & Average 55 US\$/bbl (2010) \\
\hline & Increase $+5 \% /$ decade from 2010 onwards \\
\hline \multirow[t]{9}{*}{ Price of other and primary fuels } & For year 2000: \\
\hline & Electricity: $12 \mathrm{US} \$ / \mathrm{GJ}$ \\
\hline & Natural gas: $6 \mathrm{US} \$ / \mathrm{GJ}$ \\
\hline & Hard coal: 2 US/\$GJ \\
\hline & Biomass: 4 US\$/GJ \\
\hline & Gasoline: linear relation to price of oil \\
\hline & Diesel: linear relation to price of oil \\
\hline & Time dependant changes based on \\
\hline & $\begin{array}{l}\text { resource balance and availability of } \\
\text { resources }\end{array}$ \\
\hline $\begin{array}{l}\text { Growth of aggregated parts of the transpor- } \\
\text { tation sector }\end{array}$ & $+5 \% /$ decade \\
\hline $\begin{array}{l}\text { Improvement of fuel efficiency for vehicles } \\
\text { (excluding } \mathrm{H}_{2} \text { fuel cell based vehicles) }\end{array}$ & $+5 \% /$ decade \\
\hline $\begin{array}{l}\text { Maximal growth of hydrogen infrastructure } \\
\text { for the Base Case }\end{array}$ & $+10 \% /$ decade \\
\hline
\end{tabular}

fuelling their hydrogen fuel cell vehicles. In order to break this "chicken\&egg" problem, an external incentive is required. The fuel cell developers and manufacturers have invested significant sums during the first quarter of the century and could be reluctant to continue investments at such a pace (mobile fuel cell would remain as back-stop technology, with perspective of launching at later time) while only a marginal share of individual users would be willing to commit themselves to investments into vehicles with extremely limited access to fuelling network. Therefore, the remaining potential body which could provide the initiative for the switch to hydrogen based mobility is the government.

\section{Supporting hydrogen fuel cells}

The settings of the Base-case, based on today's information about costs of fuel cells, their stage of development, prices of available fuels, etc. clearly indicates that primarily because of high initial costs of fuel cells, the penetration of fuel cell vehicles is not feasible. Nevertheless, the transition towards hydrogen based transportation systems is broadly discussed. We therefore apply the GMM model to evaluate the market penetration of hydrogen fuel cell vehicles and analyze different policy constraints aiming at investigating the conditions for the hydrogen systems to emerge.

In the numerical experiments with GMM, we attempt to influence the initial parameters (in terms of installed capacity and cost) of the fuel cell vehicles and assess alternative policy measures: firstly "demand pull" options are introduced where the governments or the car manufactures directly influence the market 


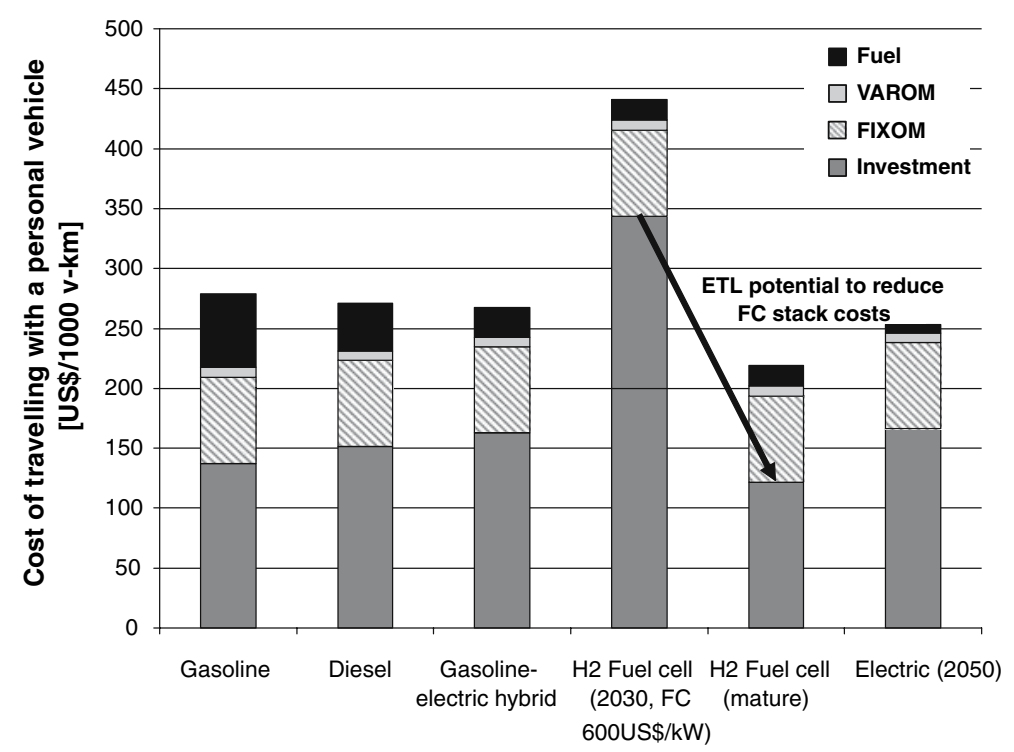

Fig. 3 Costs structure of travel with a personal vehicle as used in analysis with GMM

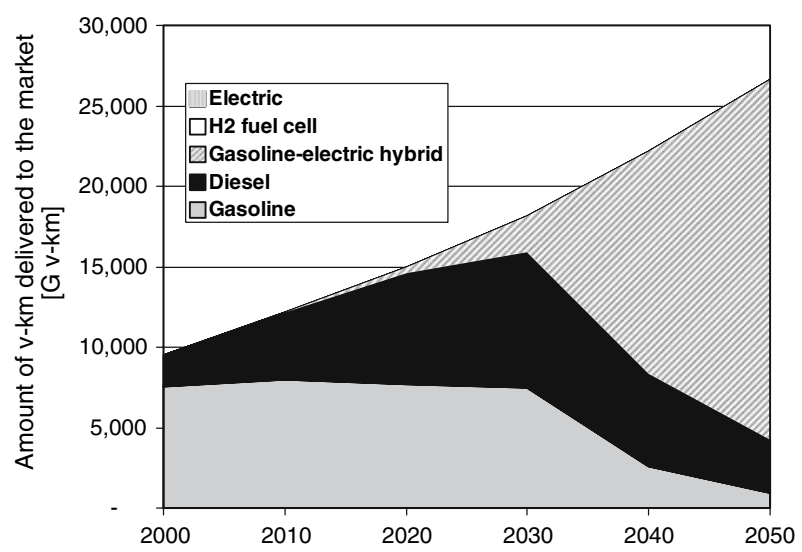

Fig. 4 GMM base case, graphical illustration of the personal vehicle sub-sector

price of fuel cell stack by means of R\&D support or demonstration projects or subsidies (the so-called "learning investments"). Also in parallel to the measures above or as a stand alone policy option, we internalize the external cost that take place in the transportation sector. Finally, we analyze "supply push" policy options that directly influence the production price of hydrogen. We start with the presentation of policies related with environmental externalities in the transportation sector. 


\subsection{Environmental externalities in transportation}

Hydrogen fuel cell vehicles are, in terms of environmental performance, by far superior to the current transportation systems as no emissions are produced during the operation of the vehicles. This fact opens the opportunity for policy interventions, aiming at penalization of technologies which are associated with external costs. From the governmental point of view this may be well justified as conventional technologies are strongly bound to externalities (side effects). These externalities originate from greenhouse gases that induce climate change and the emission of local pollutants, carrying with them a potential for deteriorating health of humans in terms of increasing acute morbidity, chronic morbidity, mortality and cancer (McCubbin and Delucchi 1999). In general, GMM integrates the externality taxes (EXCST) in the calculation of the cost per km traveled based on the following relationship (11):

$$
\begin{aligned}
\operatorname{CKM}(\$ / \mathrm{kV} \mathrm{km})= & \frac{\operatorname{PPV}(\$) \times \mathrm{CRF}+\operatorname{FIXOM}(\$ / \text { year })}{17.5 \cdot(\mathrm{kVkm} / \text { year })} \\
& +\operatorname{VAROM}(\$ / \mathrm{kV} \mathrm{km})+\frac{\operatorname{FUEL}(\$ / \mathrm{GJ})}{\eta(\mathrm{kVkm} / \mathrm{GJ})}+\operatorname{EXCST}(\$ / \mathrm{kg}) \\
& \times \operatorname{EM}(\mathrm{kg} / \mathrm{kV} \mathrm{km}), \text { with } \operatorname{CRF}(1 / \text { year })=\frac{\delta(1+\delta)^{T}}{(1+\delta)^{T}-1}
\end{aligned}
$$

where $\mathrm{CKM}=$ cost per $\mathrm{km}$; $\mathrm{PPV}=$ purchase price of vehicle; $\mathrm{CRF}=$ capital recovery factor; FIXOM = fixed O\&M cost; VAROM = variable O\&M cost; FUEL=fuel cost; $\eta=$ efficiency; EXCST = external cost per unit of emission; $\mathrm{EM}=$ specific emission factor; $\delta=$ discount rate; and $T($ year $)=$ car lifetime.

To address the issue of assigning costs related to the negative impacts of externalities, we have conducted an analysis in which we have included the external costs per unit of emissions of $\mathrm{CO}_{2}, \mathrm{SO}_{2}$, and $\mathrm{NO}_{x}$ coming from the transportation sector. The estimated costs related to externalities have two main short-comings. Firstly, they are uncertain and display quite a broad range of estimated costs (a range between 25 and $650 \mathrm{US} \$ /$ ton of $\mathrm{CO}_{2}$ and in the range of 520 to over 70,000 US $\$$ /ton of emitted pollutant) and secondly data are limited to only few world regions (mainly Western Europe and the State of California in USA) (McCubbin and Delucchi 1999; Ogden et al. 2001). Therefore, following the available studies we have calculated average values for regional externalities associated with selected pollutants and scaled them to fit the GMM regional division. Average values have been calculated on the basis of the Externe Project (McCubbin and Delucchi 1999; Ogden et al. 2001).The scaling has been defined relating the costs of a given pollutant to the per capita gross domestic product expressed in terms of purchasing power parity (GDP/PPP) (Markandya and Boyd 1999; Hirschberg et al. 2003; Rafaj 2005). As first step of the procedure, the methodology creates a "scaling factor" between regions of different population density. This is obtained by comparing the density of the 
tested region with the population density of region covered by reference studies (i.e., Western Europe and Asia). This scaling factor is presented in Table 6.

Next, in order to capture the differences in the regional economic development level and allow for linking to the reference value of externalities for Western Europe, an equation is established which references the GDPPPP/capita of the analyzed region to the reference region of Western Europe:

$$
\mathrm{EXT}_{\text {region,time }}=\mathrm{EXT}_{\text {WesternEurope,2000 }}^{\text {reference_value }} \times \frac{\mathrm{GDP}_{\mathrm{ppp}, \text { time }}^{\text {region }}}{\mathrm{GDP}_{\mathrm{ppp}, 2000}^{\text {WesternEurope }}}
$$

Having established the scaling relationship for the population density (Table 6) and using the IIASA B2 economic development scenario for GDPPPP (Riahi and Roehrl 2000) the overall externality scaling factors are calculated for the consecutive time periods and regions of GMM (Table 7; Fig. 5).

The mentioned time dependant external costs per unit of emissions are then introduced in GMM to generate a scenario in which the negative impacts of emissions originating from the transportation sector are charged as externalities to balance out the effect. The results are presented in Fig. 6.

As compared to the base case (Fig. 4), the results of the case suggest that if the external costs are internalized, the dominating role in the later part of the analysis timeframe would be played by the gasoline-electric hybrid vehicles. This is due to the fact that gasoline-electric hybrid vehicles, despite being based on gasoline, display much better fuel and environmental performances as compared to conventional gasoline or diesel vehicles. As the fuel cell vehicles

Table 6 Scaling of externalities - population density factors

\begin{tabular}{lllll}
\hline Determinant for scaling & & $\mathrm{SO}_{2}$ & $\mathrm{NO}_{x}$ & Region \\
\hline Population density factor & High & 1.5 & 1.5 & OOECD, ASIA \\
& Moderate & 1.0 & 1.0 & NAM, EEFSU, LAFM \\
\hline
\end{tabular}

Table 7 Values of external costs and regions specific scaling factors

\begin{tabular}{|c|c|c|c|c|c|}
\hline \multirow[t]{2}{*}{ Region } & \multicolumn{5}{|c|}{ Time period } \\
\hline & 2010 & 2020 & 2030 & 2040 & 2050 \\
\hline NAM & 2.0 & 2.2 & 2.3 & 2.5 & 2.8 \\
\hline OOECD & 1.3 & 1.5 & 1.6 & 1.7 & 1.8 \\
\hline EEFSU & 0.4 & 0.5 & 0.7 & 0.9 & 1.1 \\
\hline ASIA & 0.3 & 0.4 & 0.5 & 0.6 & 0.7 \\
\hline LAFM & 0.2 & 0.2 & 0.3 & 0.4 & 0.5 \\
\hline \multicolumn{6}{|c|}{ Reference values } \\
\hline $\mathrm{CO}_{2}$ & $25 \mathrm{~L}$ & \multirow{2}{*}{\multicolumn{4}{|c|}{$\mathrm{CO}_{2}$ is not undergoing scaling }} \\
\hline $\mathrm{NO}_{\mathrm{x}}:$ & $6,500 \mathrm{US} \$ /$ ton & & & & \\
\hline $\mathrm{SO}_{2}:$ & \multicolumn{5}{|c|}{$9,300 \mathrm{US} \$ /$ ton } \\
\hline
\end{tabular}




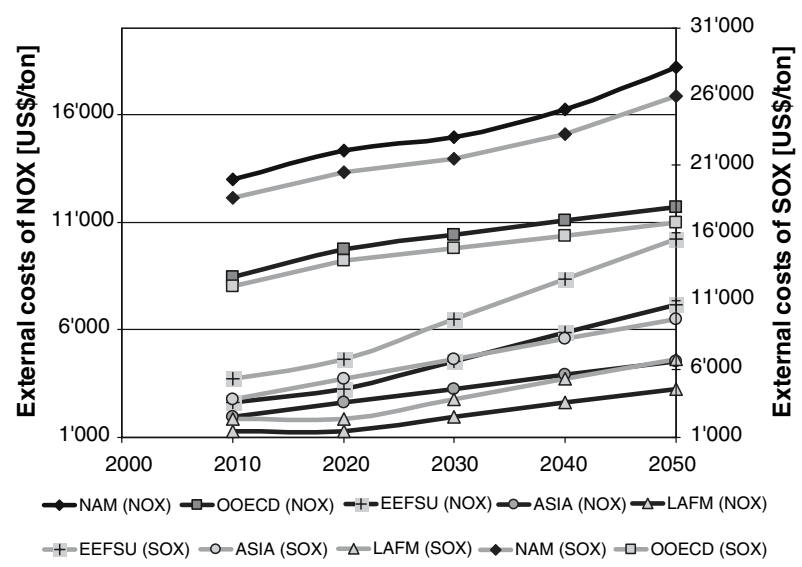

Fig. 5 Value of externalities $\left(\mathrm{SO}_{2}\right.$ and $\left.\mathrm{NO}_{x}\right)$ for GMM with world regions and time

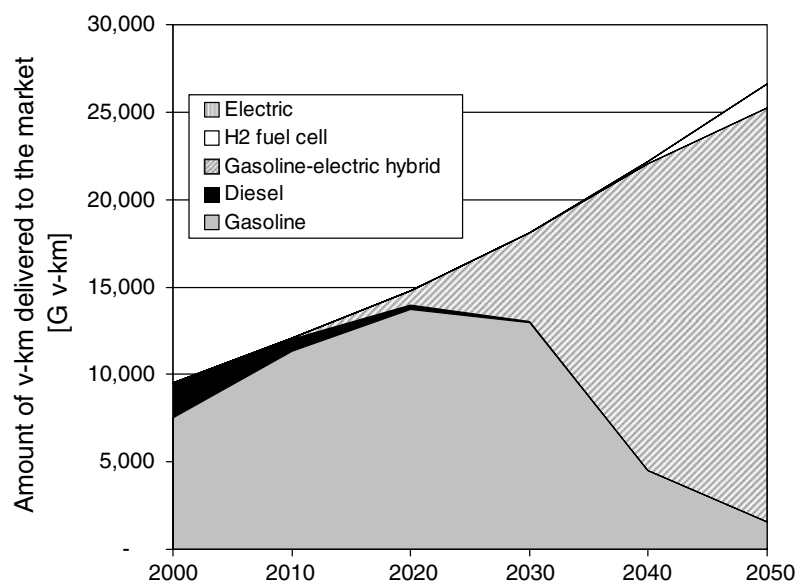

Fig. 6 GMM externality case

become matured, one can observe the switch towards hydrogen in the last decade of the time horizon of the analysis.

Nevertheless, introduction of measures which would fully cover the estimated damages (Fig. 5) caused by the pollution coming from the transportation sector could require very harsh fiscal measures. Therefore, in the subsequent part of this work we describe via sensitivity analyses, less drastic but sufficient measures for supporting a sustainable development in the transportation sector.

\subsection{Sensitivity analyses on external costs}

In the sensitivity analysis we assume that governments are willing to initiate the switch towards a more sustainable transportation system by firstly internalizing 

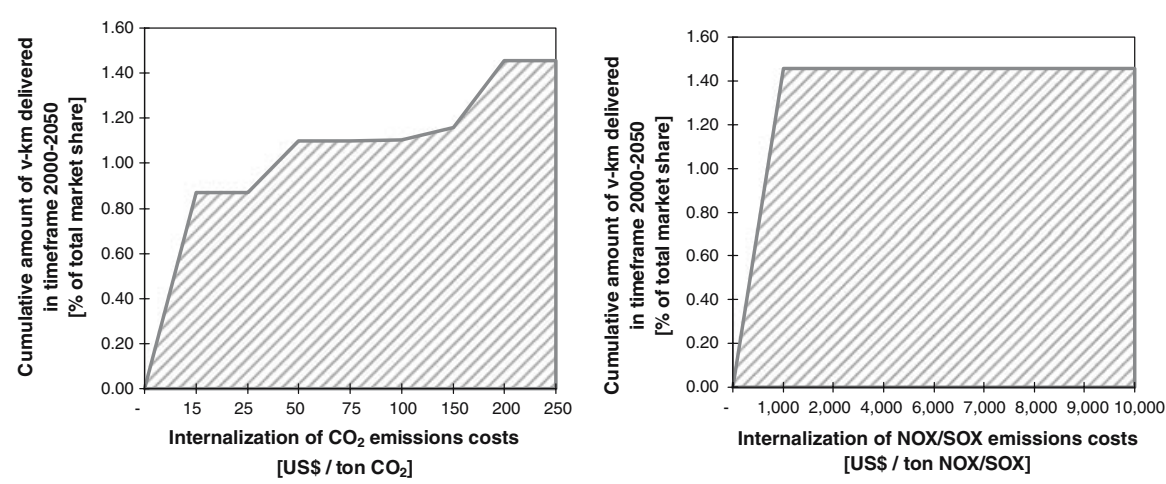

Fig. 7 Sensitivity analysis of the potential impact of $\mathrm{CO}_{2}$ and local pollutants internalization, on the market penetration of hydrogen fuel cell vehicles

the external costs related to the $\mathrm{CO}_{2}$ emissions coming from the production of fuel and the operation of vehicles followed by the externalities related to local pollutants. From the modeling perspective both externalities change the costs structure in transportation by increasing the price of fossil fuels. ${ }^{1}$ Therefore, in our analysis we consider externalities related to $\mathrm{NO}_{x}, \mathrm{SO}_{2}$ and particulate matter as a distant alternative in the case that all other policy measures are insufficient. We therefore performed a series of optimization experiments varying the tax level and results are presented in (Fig. 7). Moreover, an additional set of graphs has been presented for the case of imposing a penalty of 100 US\$/ton $\mathrm{CO}_{2}$ (Fig. 8) describing the regional resolution of results.

The results of our analysis suggest that even minor cost reductions are sufficient to trigger the change towards hydrogen based mobility. Nevertheless, one should bear in mind that environmental externalities influence also the fossil fuel based hydrogen production. However, despite the additional costs related to externalities, hydrogen can always be attractive as the price of hydrogen rises significantly less than the price of oil-based fuels.

\subsection{Demand Pull via RD\&D support}

First and in order to assess "demand pull" options, we directly support hydrogen systems by different means of compensating mobile fuel cell vehicle customers with a fixed reimbursement for every $\mathrm{kW}$ of fuel cells purchased. This type of promotion policy has been adopted from already existing, real-market solutions (Katz and Payne 2000; Payne and Katz 2000; Somasundaram 2004).

The "learning investments" strategy assumes promoting fuel cell vehicles by means of a series of demonstration cars at more favorable prices to the end consumer. In real terms this leads to a preliminary market launch of fuel cell

\footnotetext{
1 The alternative is to introduce strict environmental standards on local pollutants (examples of this can be the European EURO or the American CAFE emissions standards).
} 

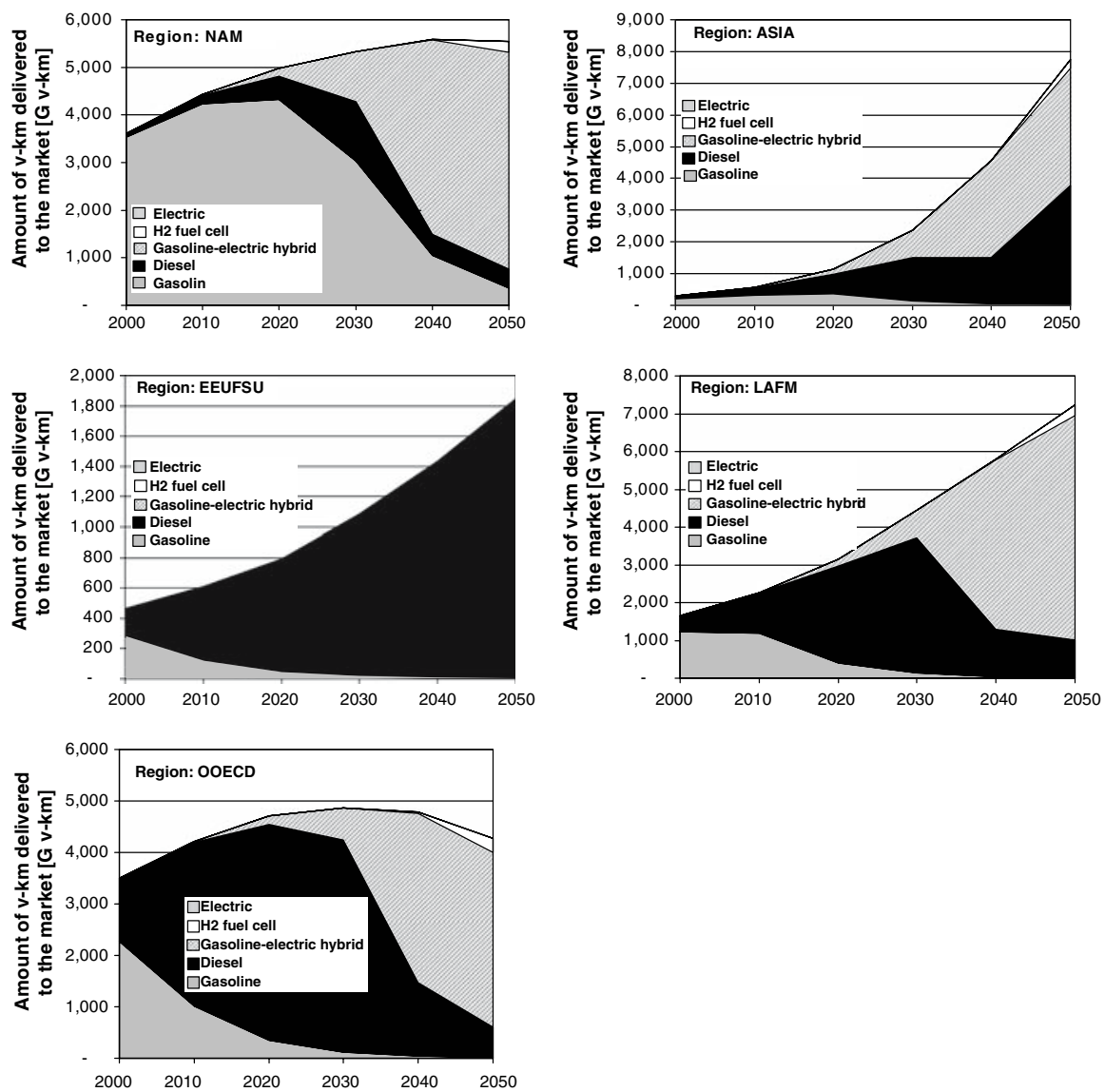

Fig. 8 Illustrative snapshot of regionalized market penetration of different types of vehicles for the case of $100 \mathrm{US} \$ /$ ton $\mathrm{CO}_{2}$ penalization. The model takes into consideration the regional circumstances when allocating technologies in the markets

vehicles at prices lower than their actual value. This approach allows increasing the production of fuel cell based vehicles via price reductions and more sales and as the experience in fabricating and operating the new systems increases, a positive feed-back loop is established.

The demonstration launches could be pictured in Fig. 9 and in Table 8. At the time the fuel cell vehicles are ready to enter the market, they are still at an uncompetitive level. Therefore, an initiative could be formed to support e.g., the first 60,000 vehicles that may be purchased at a discount of $100 \mathrm{US} \$ / \mathrm{kW}$ (giving a benefit of 5,000 US\$/vehicle). However, these sales will result to a significant cost reduction induced by the endogenous learning mechanism and the price of fuel cell stack will fall down to $380 \$ / \mathrm{kW}$. The following diagram illustrates the induced cost reduction. 


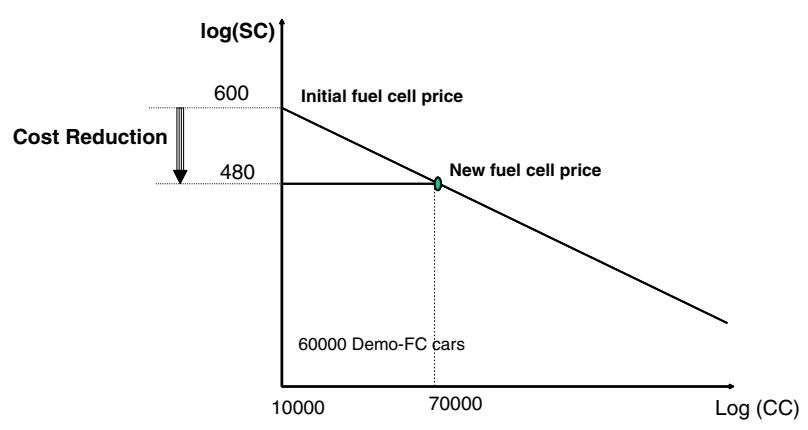

Fig. 9 Demonstration projects - graphical illustration of costs reduction

Table 8 Change of the specific cost of fuel cells as result of demonstration projects

\begin{tabular}{|c|c|c|c|c|c|c|}
\hline Learning rate & $15 \%$ & & & & & \\
\hline $\mathrm{SC}_{0}$ & $600 \mathrm{Us}$ & & & & & \\
\hline $\mathrm{CC}_{0}$ & 10,000 & & & & & \\
\hline Demo Vehicles & None & 12,500 & 20,000 & 50,000 & 60,000 & 150,000 \\
\hline $\mathrm{SC}$ & 600 & 496 & 464 & 394 & 380 & 313 \\
\hline
\end{tabular}

Reading the presented diagram (Fig. 9) and considering the mathematical expression of ETL costs reduction using the following Eq. (13): ${ }^{2}$

$$
\mathrm{SC}(\mathrm{CC})=\mathrm{SC}_{0} \times\left(\frac{\mathrm{CC}}{\mathrm{CC}_{0}}\right)^{-b} \text { and } \quad \mathrm{b}=\frac{\ln (1-0.15)}{\ln 2}
$$

one may define how the initial cost of the fuel cells and the initial cumulative installations change ${ }^{3}$ (Table 8).

This set of initially supported demonstration projects and the corresponding reduced specific cost is introduced in GMM in a sensitivity assessment and defines the potential influence of this strategy. The diagram below illustrates the outcomes of this strategy (Fig. 10).

The results are very optimistic as a minimum amount of "learning investments" in form of demonstration vehicles could renter hydrogen fuel cell cars competitive. This is again explained as a consequence of the high learning rate assumed and the significant number of cumulative doublings obtained.

\footnotetext{
2 SC defines the specific cost (at given cumulative market penetration), $\mathrm{SC}_{0}$ the initial cost (starting cost at the time the fuel cells are introduced to the market), CC the cumulative number of fuel cell vehicles, $\mathrm{CC}_{0}$ the initial number of fuel cell vehicles launched to the market and $b$ the learning coefficient.

3 The same impact can be gained if Government or Private R\&D spending improves the experience in manufacturing and operating fuel cell stacks reducing their price in the end-use markets. In that case, instead of moving along the learning curve to the new initial point with coordinates (380, 60000) we will move directly down in the vertical axis starting a new learning curve of the same slope but below the one shown in Fig. 9.
} 


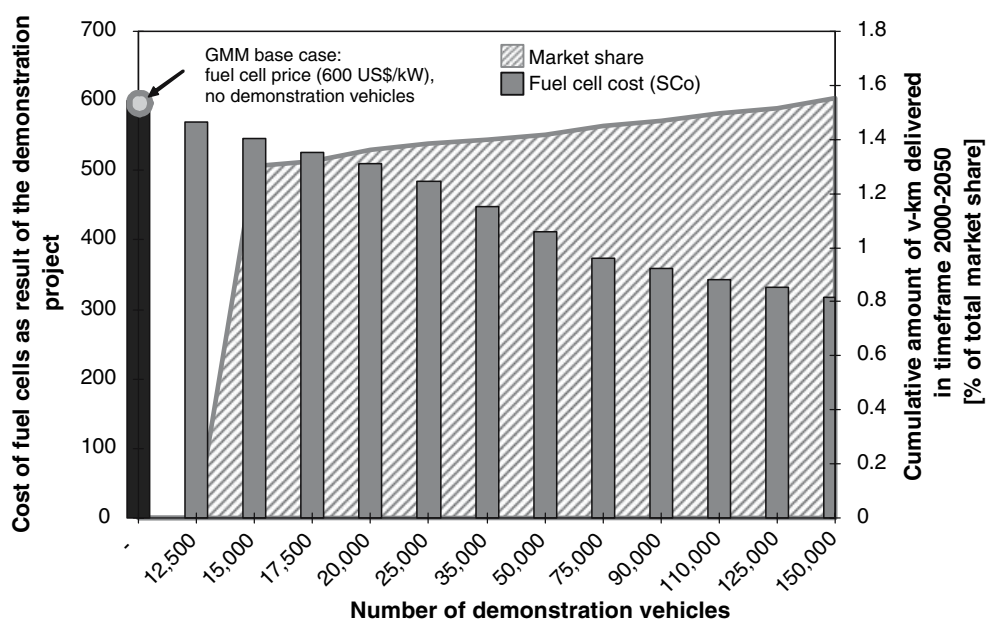

Fig. 10 Demonstration projects - graphical illustration of market penetration

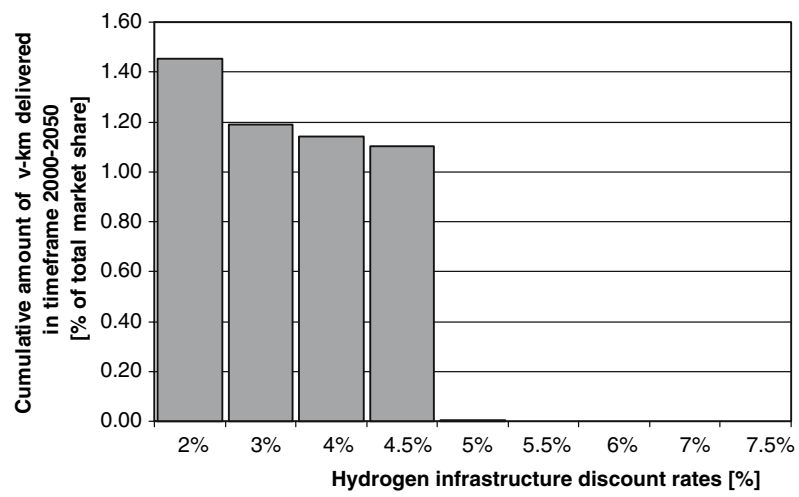

Fig. 11 Sensitivity analysis of the potential impact of preferential discount rates for hydrogen infrastructure build up on the market penetration of hydrogen fuel cell vehicles

\subsection{Supply push}

A second set of options has been analyzed in which the government may allow for preferential credits for hydrogen infrastructure buildup projects (lower discount rates for infrastructure). This tactic aims at reducing the fuel cost component of fuel cell vehicles. Similar support could be also considered in the production facilities of hydrogen.

The case study with GMM considered the impact of preferential credits for projects which result in the development of hydrogen infrastructure (fuelling stations, pipelines, local and central generation plants, etc.). The results of the analysis are presented below (Fig. 11).

Figure 11 indicates that the average discount rates which have been assumed for the runs with GMM (5\%) keep the hydrogen based mobility on a 
go/no-go break-even point. Thus, there is a potential of promoting hydrogen based mobility, with preferential credits for hydrogen infrastructure projects which results in reducing the cost of the money invested in infra-structures.

Finally, combined strategies could be also analyzed where the tax revenue due to the internalization of local and global externalities $\left(\mathrm{PM}, \mathrm{NO}_{x}, \mathrm{SO}_{2}\right.$ and $\mathrm{CO}_{2}$ ) could be partially used to subsidize learning investments either in the demand or the supply side and help the technology to follow its learning curve.

\section{Conclusions}

The purpose of the study was twofold: first to analyze conditions for the hydrogen economy to succeed in substituting for oil and second to explain how this analysis was done with the help of the GMM model that models endogenous technology dynamics. Our approach was based on well justified policies promoting hydrogen vehicles and/or correcting for negative externalities of non-sustainable transportation technologies based on the principles of environmental economics.

In this article we present results of the assessment carried out with GMM, aiming at establishing ways for an efficient support of the transition towards hydrogen based transportation. Hydrogen based transportation is discussed broadly as an environmentally sound alternative to the current, oil-based transportation. Despite the fact that from today's perspective many question the viability of the hydrogen based transportation alternative, this transition could take place in the long run, based on our optimization experiments performed with GMM.

Our analysis started with increasing of costs of environmentally unfriendly technologies. This was achieved by introduction of environmental penalties for externalities. The result of this part of the analysis has shown that introduction of a carbon tax of $50 \mathrm{US} \$ /$ ton $\mathrm{CO}_{2}$ provides a benefit to hydrogen cars. Another option would be to internalize for externalities related to local pollutants. Not the full range of external cost has to be internalized in order to help the penetration of hydrogen fuel cell cars.

In the next exercise, we targeted the possibility of "demand push" options that reduce the cost of fuel cells. This has been achieved by introduction of 'cash-back' promotions and demonstration vehicles. Both of these instruments have already been applied for the cases of hybrid-electric and electric vehicles. In this approach a reduction in price of $50 \mathrm{US} \$ / \mathrm{kW}$ proved to have a favorable influence on market penetration, while a demonstration and deployment program would allow to increase the cumulative experience and further reduce costs of fuel cells. Similar results could be obtained with an intensive private or government R\&D spending.

In a further attempt to even the price difference between hydrogen and conventional vehicles, we have focused on another element of the cost structure, namely the price of hydrogen ("supply push" options). In this case we introduced lower discount rates for the hydrogen network, in order to deliver 
cheaper hydrogen. This instrument is a well known mechanism for promotion of renewable energy such as solar PV panels, and is delivered to the market in form of preferential crediting options. The results of this part of the analysis have suggested that lowering initial discount rates from 5\% to $3 \%$ would be sufficient to initiate a successful market penetration of fuel cell vehicles. Other supply supporting options can be introduced to help hydrogen production. These options can also be financed utilizing the tax revenue related to local externalities.

Our analysis has shown that despite high initial costs, a transition to hydrogen based transportation could be feasible in the long run provided a number of concurrent developments take place. However, a considerable number of hurdles exist that would have to be overcome. Thus, such long-term transition would require significant external support, such as governmental aid in form of RD\&D support and in "learning investments" to help the technologies to follow their learning curve and become competitive in the long run.

The energy-system GMM integrates all energy sectors and describes an endogenous treatment of energy reserves and resources, contains a broad range of supply and demand technologies that allow studying long-term dynamics and developments and policy implications in the world-regional markets. Nevertheless, a number of limitations inherent to this optimization, perfect foresight modeling framework must be borne in mind when interpreting the results of this study. Recursive dynamic models that incorporate consumer's preferences could be an alternative option to study medium-term options in the transportation sector. Such version of MARKAL is the SAGE model of DOE/EIA which is not yet available for broad use (Loulou et al. 2004).

Acknowledgements The work presented herein has been carried out with the financial support of the Swiss National Centre of Competence in Research on Climate (NCCR-Climate) funded by the Swiss National Science Foundation (SNSF) and the EU project CASCADE-MINTS. The support is gratefully acknowledged.

\section{References}

Babiker MH, Reilly JM et al (2001) The MIT emissions prediction and policy analysis (EPPA) model: revisions, sensitivities, and comparisons of results. Joint Program on the Science and Policy of Global Change: 92, Massachusetts Institute of Technology, Cambridge, MA, USA

Barreto L, Kypreos S (2004) Endogenaizing R\&D and market experience in the "bottom-up" energy-systems ERIS model. Technovation 24(8):615-629

BP (2005) Putting energy in the spotlight BP Statistical Review of World Energy, June 2005, England

BTS U (2000) North American transportation in figures. Bureau of Transportation Statistics, Department of Transportation, Washington, DC

Contadini JF (2000) Social cost comparison among fuel cell vehicle alternatives. In: 35 th intersociety energy conversion engineering conference, American Institute of Aeronautics and Astronautics, Inc. Las Vegas, NV, USA

Hekkert MP, Faaij APC et al (2004) Natural gas as an alternative to crude oil in automotive fuel chains well-to-wheel analysis and transition strategy development. Energy Policy (in press)

Heston A, Summers R et al (2002) Penn World Table Version 6.1. Center for International Comparisons at the University of Pennsylvania (CICUP) 
Hirschberg S, Heck T et al (2003) Environmental impact and external cost assessment. Kluwer Academic Publishers, Doldrecht

IEA (International Energy Agency) (2002a) Beyond Kyoto energy dynamics and climate stabilisation. International Energy Agency, Paris

IEA (International Energy Agency) (2004) Energy technologies for a sustainable future: transport. IEA Technology Briefs. International Energy Agency, Paris, France

IFTA (2004) From http://www.iftach.org/

Katz D, Payne H (2000) TH!NK Again About Eco-Cars. Wall Street J

Laitner JAS, Sanstad AH (2004) Learning-by-doing on both the demand and the supply sides: implications for electric utility investments in a heuristic model. Int J Energy Technol Policy 2(1/2):142-152

Litman TA (2003) Transportation cost and benefit analysis - techniques, estimates and implications. Victoria Transport Policy Institute, Victoria BC, Canada

Loulou R, Goldstein G et al (2004) Documentation for the MARKAL family of models, energy technology systems analysis programme

Luxembourg Office for Official Publications of the European Communities (2001) Transport and Environment-Statistics for the transport and environment reporting mechanism (TERM) for the European Union. Luxembourg, Belgium

Markandya A, Boyd R (1999) Economics of greenhouse gas limitations. Collaborating Centre on Energy and Environment, Riso National Laboratory, UNEP, Denmark

McCubbin DR, Delucchi MA (1999) The health costs of motor-vehicle-related air pollution. J Transp Econ Policy 33:253-286

Metschies GP (2001) Fuel prices and vehicle taxation. Deutsche Gesellschaft für Technische Zusammenarbeit (GTZ) GmbH

Nakicenovic N, Swart R (2000) Special report on emissions scenarios: a special report of working Group III of the Intergovernmental Panel on Climate Change

OECD (2003) General OECD web-site information. Retrieved 16.07.2003, 2003, from http://www.oecd.int/document/58/0,2340,en_2649_34483_1889402_1_1_1_1,00.html

Ogden JM, Williams RH et al (2001) Toward a hydrogen-based transportation system (Final draft 8 May 2001). Center for Energy and Environmental Studies, Princeton, NJ

Ogden JM, Williams RH et al (2004) Societal lifecycle costs of cars with alternative fuels/engines. Energy Policy 32(1):7-27

Payne H, Katz D (2000) Car Crazy: Al Gore, automotive engineer

Pelkmans L, De Keukeleere D et al (2001) Emissions and fuel consumption of natural gas powered city buses versus diesel buses in real-city traffic. VITO-Flemish Institute for Technological Research (Belgium)

Rabl A, Spadaro JV (2000) Health Costs of Automobile Pollution. Rev. Fran. Allergol Immunol Clinique 40(1):55-59

Rafaj P (2005) Analysis of policies contributing to sustainability of the global energy system using the global multi-regional MARKAL model (GMM). Swiss Federal Institute of Technology Zurich (ETH Zurich); vol 204, Chemistry Department, Zurich, Switzerland

Riahi K, Roehrl AR (2000) Greenhouse gas emissions in a dynamics as usual scenario of economic and energy development. Technol Forecast Soc Change 63(2-3):175-205

Schafer A, Victor DG (2000) The future mobility of the world population. Transp Res A Policy Pract 34(3):171-205

Simbeck DR, Chang E (2002) Hydrogen supply: cost estimate for hydrogen pathways - scoping analysis. National Renewable Energy Laboratory vol 71, Golden, Colorado (USA)

Somasundaram N (2004) Japan hands REVA \$2,600 welcome note. REVA-News Articles Retrieved 26.01.2006, from http://www.revaindia.com/2004_4.htm

Suurs R (2002) Long distance bioenergy logistics - an assessment of costs and energy consumption for various biomass energy transport chains. Utrecht University, Utrecht

Toyota (2003) Toyota Prius - specifications sheet

US Department of Transportation, Bureau of Transportation S. (2002) National transportation statistics 2002. Governmental Printing Office, Washington, DC, USA

US Department of Transportation, Bureau of Transportation S., US Department of Commerce, Census Bureau; Statistics Canada; Transport Canada; Instituto Me xicano del Transporte; Instituto Nacional de Estadistica, Geografia e Informatica; Secreretaria de Communicaciones 
y Transportes (2000). North American transportation in figures (BTS00-05). Washington, DC, USA

Wokaun A, Baltensperger U et al (2004) The role of hydrogen in a future sustainable energy system, under which circumstances does a hydrogen economy make sense? Villigen, Switzerland, Paul Scherrer Institute; Villigen, Switzerland; ETH Zuerich, Switzerland

World Energy Council (1998) Global transport and energy development: the scope for change. World Energy Council

World Energy Council and International Institute for Applied Systems Analysis (IIASA) (1998) Global energy perspectives. UK, Cambridge University Press, Cambridge, 